\title{
Perbandingan Efektivitas Model Pembelajaran Kooperatif Picture and Picture dan NHT Dalam Pembelajaran IPS Tingkat SD
}

\section{Made Harman Sulaksana ${ }^{*}$, I Made Citra Wibawa ${ }^{2}$, Ni Wayan Arini ${ }^{3}$}

${ }^{123}$ Program Studi Guru Sekolah Dasar, Universitas Pendidikan Ganesha, Singaraja, Indonesia

\begin{tabular}{l} 
A R T I C L E I N F O \\
\hline Article history: \\
Received 1 Januari 2021 \\
Received in revised form \\
30 Januari 2021 \\
Accepted 1 Maret 2021 \\
Available online 8 April \\
2021 \\
\hline Kata Kunci: \\
picture and picture, \\
NHT, IPS \\
Keywords: \\
picture and picture, NHT, \\
IPS
\end{tabular}

ARTICLEINFO

Received 1 Januari 202 Received in revised form 30 Januari 2021

Acepted 1 Maret 2021

(1) 8 April

Kata Kunci: picture and picture picture and picture, $N H T$ IPS

\begin{abstract}
A B S T R A K
Kurang maksimalnya guru dalam memanfaatkan model pembelajaran dan penggunaan alat peraga selama proses pembelajaran IPS serta kurangnya motivasi belajar akan sangat berpengaruh pada keberhasilan siswa. Untuk mengatasi permasalahan tersebut, diperlukan model pembelajaran yang tepat agar siswa mampu mengikuti pembelajaran. Penelitian ini bertujuan untuk menganalisis perbandingan efektivitas dari penerapan model pembelajaran kooperatif tipe picture and picture dan NHT untuk meningkatkan hasil belajar IPS tingkat SD. Jenis penelitian ini adalah penelitian meta analisis dengan cara review naratif dan sistematik artikel ilmiah. Subjek penelitian ini adalah model pembelajaran kooperatif tipe picture and picture dan NHT pada mata pelajaran IPS tingkat SD. Metode pengumpulan data yang dilaksanakan melalui penulusuran jurnal online dari google scholar dengan total 10 artikel yang dipilih dari setiap tipe pembelajaran membahas 5 artikel ilmiah. Teknik analisis data yang digunakan adalah teknik analisis data statistik deskriptif kuantitatif. Hasil penelitian ini menunjukkan nilai gain yang diperoleh dari hasil penerapan model pembelajaran kooperatif tipe picture and picture memiliki
\end{abstract} nilai rata-rata 2,83, sedangkan pada tipe NHT memiliki nilai rata-rata 19,74. Simpulan penelitian ini adalah model pembelajaran kooperatif tipe NHT lebih efektif untuk diimplementasikan dalam pelajaran IPS siswa SD. Implikasi penelitian ini adalah meningkatkan motivasi belajar, kemampuan berpikir kritis, siswa akan aktif selama pembelajaran dan dapat meningkatkan hasil belajar siswa.

\begin{abstract}
A B S T R A C T
The teacher's lack of maximal use of the learning model and the use of teaching aids during the social studies learning process and the lack of learning motivation will greatly affect student success, to overcome these problems, an appropriate learning model is needed so that students are able to participate in learning This study aims to analyze the comparison of the effectiveness of the application of the picture and picture and NHT cooperative learning model to improve social studies learning outcomes at the elementary level. This type of research is a meta-analysis research by means of a narrative and systematic review of scientific articles. The subject of this research is the picture and picture and NHT cooperative learning model in the social studies subject at the elementary level. The data collection method was carried out through online journal research from Google Scholar with a total of 10 articles selected from each type of learning discussing 5 scientific articles. The data analysis technique used is descriptive quantitative statistical data analysis techniques. The results of this study indicate the gain value obtained from the application of the picture and picture type cooperative learning model has an average value of 2.83, while the NHT type has an average value of 19.74. The conclusion of this research is that the NHT type cooperative learning model is more effective to be implemented in elementary school students' social studies lessons. The implication of this research is to increase learning motivation, critical thinking skills, students will be active during learning and can improve student learning outcomes.
\end{abstract}




\section{Pendahuluan}

IPS merupakan pelajaran yang abstrak dan verbal tentang berbagai kenyataan sosial dalam kehidupan sehari-hari (Ani et al., 2017; Ilham \& Hardiyanti, 2020; Mikaningsih, 2014). Mata pelajaran IPS bertujuan agar peserta didik dapat mengenal konsep-konsep dalam kehidupan masyarakat, berpikir logis dan kritis, memiliki rasa ingin tahu, terampil dalam kehidupan sosial, memiliki komitmen dan kesadaran terhadap nilai-nilai sosial dan kemanusiaan, serta mampu berkomunikasi, bekerjasama dan berkompetensi dalam masyarakat lokal, nasional, dan global (Kristin, 2016; Pratama, 2018; Susiloningsih, 2016).

Namun kenyataannya, banyak siswa yang merasa kurang mampu dalam mempelajari IPS karena dianggap sulit dan penuh hafalan. Kurangnya motivasi dalam belajar akan sangat berpengaruh pada keberhasilan siswa (Indrawan et al., 2017; Pitriani et al., 2017; Suasaningdyah, 2018). Untuk mengatasi permasalahan tersebut, diperlukan model pembelajaran yang tepat agar siswa mampu mengikuti pembelajaran yang disampaikan oleh guru IPS.

Model pembelajaran merupakan pola yang digunakan sebagai pedoman dalam merencanakan pembelajaran di kelas, termasuk di dalamnya adalah penyusunan kurikulum, mengatur materi, menentukan tujuan-tujuan pembelajaran, menentukan tahap-tahap dalam kegiatan pembelajaran, lingkungan pembelajaran, dan pengelolaan kelas (Daryanti \& Taufina, 2020; Marina, 2016; Utama \& Sari, 2015). Pembelajaran kooperatif merupakan sebuah strategi pembelajaran yang melibatkan peran aktif siswa dalam kerjasama kelompok untuk mencapai tujuan bersama. Siswa yang belajar menggunakan model pembelajaran kooperatif akan memiliki motivasi yang tinggi karena didorong dan didukung dari rekan sebaya (Apriandi, 2012; Marasiwi, 2017; Sutriningsih et al., 2018). Dalam penerapannya, model pembelajaran kooperatif memiliki berbagai tipe dalam pelaksanaannya agar sesuai dengan tujuan yang ingin dicapai. Tujuan-tujuan tersebut antara lain: meningkatkan prestasi belajar, menerima kemajemukan latar belakang siswa dalam berkelompok, dan mengembangkan keterampilan sosial melalui belajar kelompok (Kusumawati \& Mawardi, 2016; Rahmi \& Adnan, 2019; Susanto \& Ayuni, 2017).

Model pembelajaran kooperatif menggunakan tipe picture and picture merupakan salah satu strategi pembelajaran kepada siswa agar mereka tidak merasa bosan dengan mata pelajaran IPS. Model pembelajaran picture and picture memberikan siswa contoh gambar-gambar yang sudah disiapkan oleh guru dalam bentuk kartu maupun cerita bergambar, selama pembelajaran setiap kelompok harus berdiskusi dan saling membagi tugas untuk menjelaskan setiap materi dalam gambar yang disajikan (Astuti et al., 2020; Handayani et al., 2017; Susanti \& Kusmariyani, 2017). Melalui gambar-gambar tersebut, siswa akan mengurutkan/memasangkan setiap gambar agar menjadi urutan yang logis sehingga siswa juga bisa berpikir dengan logis dan kritis, maka tujuan untuk meningkatkan motivasi belajar dan berpikir kritis akan tercapai melalui model pembelajaran kooperatif tipe picture and picture (Mayasari \& N, 2019; Passalowongi, 2020; Rosmalem, 2017).

Model pembelajaraan kooperatif lainnya yang dapat diterapkan adalah tipe Number Heads Together (NHT). Penerapan model pembelajaran kooperatif tipe NHT merupakan suatu model pembelajaran yang lebih melibatkan banyak siswa dalam menelaah materi dalam suatu pelajaran dan mengecek pemahaman siswa tentang isi pelajaran tersebut, pembelajaran ini akan lebih meningkatkan kerja sama antar siswa (Aprilia, 2018; Jahring, 2020; Murwanto, 2020). NHT adalah suatu tipe dari pengajaran kooperatif pendekatan struktural yang memberikan kesempatan kepada siswa untuk saling membagikan ide-ide dan mempertimbangkan jawaban yang paling tepat, penggunaan tipe NHT pada penerapan pembelajaran kooperatif agar siswa dapat belajar melalui kegiatan bermain, berlomba dan bekerjasama dalam tim (Elida, 2018; Sulastri, 2020; Sumarni, 2016). Siswa diajak untuk belajar berkelompok dan diberikan nomor anggota di masing-masing kepala siswa, mereka akan berdiskusi mengenai tugas dan materi yang telah diberikan oleh guru, jika guru menyebutkan nomor yang sesuai pada salah satu nomor anggota, maka siswa akan mengangkat tangan dan menjawab pertanyaannya. Melalui penerapan metode pembelajaran kooperatif tipe NHT, maka siswa akan semakin aktif selama pembelajaran dan meningkatkan hasil belajar.

Penelitian ini didukung dengan beberapa penelitian sebelumnya yaitu, pertama penelitian yang dilaksanakan oleh (Handayani et al., 2017), memperoleh hasil bahwa model pembelajaran picture and picture berbantuan media audio-visual berpengaruh terhadap kompetensi pengetahuan IPA. Kedua, penelitian yang dilaksanakan oleh (Daryanti \& Taufina, 2020), memperoleh hasil bahwa 
penggunaan media pembelajaran dalam model picture and picture untuk meningkatkan hasil belajar siswa. Ketiga, penelitian yang dilaksanakan oleh (Sumarni, 2016), memperoleh hasil bahwa penerapan model pembelajaran Numbered Heads Together dengan pemanfaatan alat peraga sederhana terbukti dapat meningkatkan kemampuan berhitung.

Tujuan penelitian ini adalah untuk menganalisis perbandingan efektivitas dari penerapan model pembelajaran kooperatif tipe picture and picture dan NHT untuk meningkatkan hasil belajar IPS tingkat SD.

\section{Metode}

Jenis penelitian ini adalah penelitian meta analisis, penelitian meta analisis, yaitu review naratif atau review sistematik dengan menganalisis hasil-hasil penelitian yang lebih dipublikasikan secara nasional yang berkaitan dengan penggunaan model pembelajaran kooperatif dalam pembelajaran IPS. Penelitian dilakukan di Program Studi Pendidikan Guru Sekolah Dasar, Fakultas Ilmu Pendidikan, Universitas Pendidikan Ganesha sejak Januari 2020.

Subjek penelitian ini adalah model pembelajaran kooperatif tipe picture and picture dan NHT pada mata pelajaran IPS tingkat SD. Artikel pada jurnal yang telah dipublikasikan secara nasional dengan kriteria: (1) ditulis oleh peneliti umum maupun mahasiswa; (2) penelitian dilakukan di Indonesia; (3) penelitian dilakukan dalam rentang tahun 2011-2020; (4) subyek penelitian berupa penggunaan model kooperatif picture and picture dan numbering heads together (NHT) dalam pembelajaran ilmu pengetahuan sosial atau IPS; (5) penelitian dilakukan pada jenjang pendidikan sekolah dasar (SD).

Metode pengumpulan data yang digunakan pada penelitian ini yaitu review literature melalui pengumpulan berbagai artikel ilmiah dan naskah publikasi yang ada pada google scholar. Hasil dari pencarian tersebut memberikan simpulan untuk membandingkan metode pembelajaran kooperatif tipe picture and picture dan tipe numbering heads together (NHT) dengan masing-masing jumlah 5 artikel ilmiah nasional.

Teknik analisis data yang digunakan adalah teknik analisis data statistik deskriptif kuantitatif. Teknik analisis ini digunakan untuk mencari hasil peningkatan belajar. Hasil peningkatan belajar ini dapat diperoleh melalui hasil rata-rata nilai seluruh siswa, persentase kenaikan belajar, maupun gain skor siswa, maka akan terdapat perbedaan nilai yang signifikan sehingga dapat diambil rata-rata perolehan gain dari masing-masing tipe pembelajaran.

\section{Hasil dan Pembahasan}

Penelitian yang dianalisis berjumlah 10 artikel. Penelitian yang digunakan diambil dari berbagai artikel pada jurnal yang dipublikasikan secara nasional yang sesuai dengan kriteria yang telah ditentukan. Untuk perbandingan metode kooperatif dari 10 artikel tersebut, tipe yang dianalisis, antara lain tipe picture and picture sebanyak 5 artikel dan numbering heads together (NHT) sebanyak 5 artikel. Hasil penelitian tersebut dapat dilihat pada Tabel 1.

Tabel 1. Data Hasil Pengelompokkan Model Pembelajaran Kooperatif

\begin{tabular}{|c|c|c|c|c|c|c|c|c|}
\hline \multirow[b]{2}{*}{ No } & \multirow[b]{2}{*}{ Peneliti } & \multicolumn{4}{|c|}{ Sub-Unit } & \multicolumn{3}{|c|}{ Peningkatan Belajar } \\
\hline & & $\begin{array}{c}\text { Jenjang } \\
\text { Pendidikan }\end{array}$ & Wilayah & $\begin{array}{l}\text { Variabel } \\
\text { Terikat }\end{array}$ & $\begin{array}{c}\text { Jenis } \\
\text { Metode } \\
\text { Kooperatif }\end{array}$ & Sebelum & Sesudah & Gain \\
\hline 1 & $\begin{array}{l}\text { (Fauziah \& } \\
\text { Bermawi, } \\
\text { 2014) }\end{array}$ & IV SD & Banda Aceh & $\begin{array}{c}\text { Ketuntasan } \\
\text { Belajar } \\
\text { Siswa }\end{array}$ & $\begin{array}{l}\text { Picture } \\
\text { and } \\
\text { Picture }\end{array}$ & 0,1 & 0,9 & 0.2 \\
\hline 2 & $\begin{array}{l}\text { (Paramita } \\
\text { dkk., 2019) }\end{array}$ & V SD & $\begin{array}{l}\text { Kediri, } \\
\text { Tabanan }\end{array}$ & $\begin{array}{l}\text { Pendidikan } \\
\text { Karakter }\end{array}$ & $\begin{array}{l}\text { Picture } \\
\text { and } \\
\text { Picture }\end{array}$ & 0,35 & 0,50 & 0,15 \\
\hline 3 & $\begin{array}{l}\text { (Tanjung, } \\
\text { 2018) }\end{array}$ & V SD & $\begin{array}{l}\text { Sabungan } \\
\text { Padangsi- }\end{array}$ & Hasil Belajar & $\begin{array}{l}\text { Picture } \\
\text { and }\end{array}$ & 0,75 & 1,00 & 0,25 \\
\hline
\end{tabular}




\begin{tabular}{|c|c|c|c|c|c|c|c|c|}
\hline \multirow[b]{2}{*}{ No } & \multirow[b]{2}{*}{ Peneliti } & \multicolumn{4}{|c|}{ Sub-Unit } & \multicolumn{3}{|c|}{ Peningkatan Belajar } \\
\hline & & $\begin{array}{c}\text { Jenjang } \\
\text { Pendidikan }\end{array}$ & Wilayah & $\begin{array}{c}\text { Variabel } \\
\text { Terikat }\end{array}$ & $\begin{array}{c}\text { Jenis } \\
\text { Metode } \\
\text { Kooperatif }\end{array}$ & Sebelum & Sesudah & Gain \\
\hline & & & $\operatorname{dimp}$ & & Picture & & & \\
\hline 4 & $\begin{array}{l}\text { (Otiarka \& } \\
\text { Susilo, } \\
\text { 2017) }\end{array}$ & V SD & Purwodadi & Hasil Belajar & $\begin{array}{l}\text { Picture } \\
\text { and } \\
\text { Picture }\end{array}$ & 0,35 & 0,96 & 0,61 \\
\hline 5 & $\begin{array}{l}\text { (Rohima } \\
\text { dkk., 2017) }\end{array}$ & III SD & Tebas & Hasil Belajar & $\begin{array}{l}\text { Picture } \\
\text { and } \\
\text { Picture }\end{array}$ & 76,50 & 88,86 & 12,36 \\
\hline \multicolumn{6}{|c|}{ Rata-Rata Peningkatan Belajar Tipe Picture and Picture } & 15,61 & 18,44 & 2,83 \\
\hline 6 & $\begin{array}{l}\text { (Nilasari \& } \\
\text { Subroto, } \\
\text { 2013) }\end{array}$ & SD & Sidoarjo & Hasil B & NHT & 57,50 & 82,60 & 25,1 \\
\hline 7 & $\begin{array}{l}\text { (Mana'a } \\
\text { dkk., 2014) }\end{array}$ & IV SD & $\begin{array}{c}\text { Tinangkung } \\
\text { Utara }\end{array}$ & Hasil Belajar & NHT & 68,45 & 85,87 & 17,42 \\
\hline 8 & $\begin{array}{l}\text { (Prasetyo, } \\
2017)\end{array}$ & IV SD & $\begin{array}{l}\text { Kulon } \\
\text { Progo }\end{array}$ & $\begin{array}{l}\text { Tingkat } \\
\text { Prestasi } \\
\text { Belajar }\end{array}$ & NHT & 62,5 & 80 & 17,5 \\
\hline 9 & $\begin{array}{l}\text { (Maponga \& } \\
\text { Anse, 2020) }\end{array}$ & VI SD & Koroha & Hasil Belajar & NHT & 73 & 81,2 & 8,2 \\
\hline 10 & $\begin{array}{l}\text { (Syah, } \\
\text { 2018) }\end{array}$ & VI SD & $\begin{array}{l}\text { Dumai } \\
\text { Selatan }\end{array}$ & Hasil Belajar & NHT & 55,25 & 85,75 & 30,5 \\
\hline \multicolumn{6}{|c|}{ Rata-Rata Peningkatan Belajar Tipe $\mathrm{NHT}$} & 63,34 & 83,084 & 19,74 \\
\hline
\end{tabular}

Pada tahap ini dilakukan penggabungan dari 10 sampel artikel yang akan dijadikan dasar dalam artikel ini. Data yang disajikan pada Tabel 1 meliputi rata-rata sebelum dan sesudah penggunaan model picture and picture dan NHT serta terlihat gain pada setiap penelitian. Berdasarkan hasil analisis pada Tabel 1 bahwa hasil belajar siswa dapat meningkat setelah diterapkan model pembelajaran picture and picture dan $N H T$, hal ini dapat dilihat dari hasil rata-rata sebelum dan sesudah diterapkan kedua tipe pembelajaran tersebut. Namun, perbedaan hasil rata-rata gain terlihat secara signifikan antara tipe picture and picture dan NHT. Dapat dilihat pada Tabel 1, rata-rata gain penerapan pembelajaran kooperatif tipe picture and picture sebesar 2,83 sedangkan pada tipe NHT sebesar 19,74. Maka, berdasarkan hasil tersebut dapat diketahui bahwa tingkat keefektifan tipe NHT lebih baik daripada picture and picture.

Hasil penelitian menunjukkan, tipe pembelajaran picture and picture dan NHT mempengaruhi hasil belajar, motivasi belajar, dan tingkat prestasi siswa dalam pelajaran IPS untuk tingkat SD. Keduanya memiliki kelebihan dan kekurangan masing-masing dalam pelaksanaan pembelajaran meskipun tetap memiliki tingkat efektivitas yang bagus. Hasil belajar setelah penerapan tergolong memiliki peningkatan yang signifikan dibandingkan dengan sebelum penerapan model pembelajaran kooperatif.

Pada penelitian milik (Fauziah \& Bermawi, 2014) dengan judul "Penerapan Model Kooperatif Tipe Picture And Picture Pada Materi Peninggalan Sejarah di Sekolah Dasar Negeri Banda Aceh" menunjukkan hasil belajar yang baik dengan nilai rata-rata yang diperoleh mencapai 82,33 dengan nilai tertinggi yang dicapai siswa adalah 100 dan nilai terendah 50. Hasil tersebut diperoleh melalui hasil tes siswa yang dianalisis dengan mengunakan statistik deskriptif, yaitu dengan menggunakan tingkat ketuntasan individu. Untuk ketuntasan belajar secara individu ditetapkan Kriteria Ketuntasan Minimal (KKM) $\geq 65$ sedangkan untuk ketuntasan secara klasikal adalah $85 \%$ siswa tuntas belajarnya. Pada penerapannya, peneliti melakukan elaborasi dengan guru pengajar dengan cara menunjukkan gambar-gambar peninggalan sejarah dan membagikan gambar kepada setiap kelompok yang terdiri dari 5 orang. Pada kegiatan akhir pembelajaran guru menyimpulkan materi pebelajaran, memberikan evaluasi (tes) dan memberikan pesan moral, kemudian mengakhiri pertemuan dengan mengucapkan salam. Hal ini dilakukan sebanyak tiga kali pertemuan untuk melihat antusiasme siswa selama pembelajaran diterapkan. Pada pertemuan ketiga, siswa diminta untuk menuliskan tentang cara 
merawat benda peninggalan sejarah yang ada pada gambar serta memberikan sesi tanya jawab antar kelompok.

Pada penelitian (Paramita et al., 2019) dengan judul "Pengaruh Model Pembelajaran Picture and Picture Berorientasi Pendidikan Karakter Terhadap Motivasi Belajar IPS Siswa Kelas V" diterapkan pada siswa kelas V SD di Gugus I Kecamatan Kediri Kabupaten Tabanan tahun pelajaran 2018/2019. Penelitian ini dilakukan menggunakan penelitian quasi eksperimen dengan rancangan non-equivalent control group design. Hasilnya, rata-rata gain skor kelompok eksperimen adalah 0,50 dan kelompok kontrol adalah 0,35. Langkah-langkah pembelajaran di kelas eksperimen mengacu pada penerapan model pembelajaran picture and picture yang berorientasi pada pendidikan karakter. Pembelajaran yang diawali dengan kegiatan bernyanyi dapat menciptakan suasana belajar menyenangkan. Untuk mempertahankan suasana belajar yang menyenangkan tersebut, siswa kemudian diajak untuk memperhatikan video dan gambar sesuai dengan materi pembelajaran. Dengan adanya tampilan video dan gambar tersebut, siswa merasa tertarik dan memiliki keinginan untuk menjawab pertanyaan-pertanyaan yang diberikan guru. Sedangkan, suasana belajar pada kelompok kontrol menunjukkan kurangnya aktivitas siswa dalam proses pembelajaran sehingga tidak semua siswa berani menyampaikan pendapat dan pertanyaan.

Selanjutnya, pada penelitian (Tanjung, 2018) dengan judul "Peningkatan Hasil Belajar Ips Melalui Model Pembelajaran Kooperatif Picture and Picture Siswa Kelas V-A SD Negeri 200402 Sabungan Padangsidimpuan 2017- 2018" memanfaatkan Penelitian Tindakan Kelas (PTK) dengan menggunakan teknik pengumpulan data non-tes (skala sikap). Hasil pembelajaran ini menujukkan perbedaan antar Siklus, yaitu skor rata-rata hasil belajar IPS pada siklus I sebesar 85,27 sedangkan pada siklus II meningkat menjadi 90,10. Adapun pada siklus I yang siswa yang menduduki hasil belajar tinggi yaitu 18 siswa (75\%) pada siklus II meningkat menjadi 24 siswa (100\%). Kenaikan skor hasil belajar IPS siswa yang menduduki hasil belajar tinggi dari siklus I ke Siklus II sebesar 25\%.

Kemudian, pada penelitian (Otiarka \& Susilo, 2017) dengan judul "Meningkatkan Hasil Belajar Siswa dengan Model Pembelajaran Kooperatif Picture and Picture Berbantuan Media Stik Keberuntungan" di SDN 02 Genengadal Purwodadi dengan jenis Penelitian Tindakan Kelas (PTK). Hasilnya menunjukkan bahwa total dari 26 siswa terdapat 24 siswa yang sebelumnya memiliki nilai di bawah KKM mengalami peningkatan 9 siswa yang memenuhi KKM pada siklus I dan meningkat lagi jumlahnya pada siklus II mencapai 25 siswa telah memenuhi KKM. Pada pembelajaran ini menggunakan bantuan talking stick dengan cara menggunakan stik bekas es krim yang diberi tugas di dalam kertas kecil kemudian ditempelkan di badan stik tersebut lalu diberikan ke sejumlah kelompok untuk dikerjakan dalam kelompok. Kemudian setiap perwakilan dalam kelompok mengambil stik tersebut dan kembali ke kelompok untuk kemudian berdiskusi dan menyelesaikan tugas dari guru tersebut.

Terakhir adalah penelitian milik (Rohima et al., 2017) dengan judul "Pengaruh Model Pembelajaran Kooperatif Teknik Picture and Picture Terhadap Hasil Belajar IPS Siswa SD". Jenis eksperimen yang digunakan adalah quasi eksperimen dengan bentuk desain eksperimen Pretest Posttest Control Group Design. Pembelajaran dilakukan dengan guru memperlihatkan gambar-gambar yang berkaitan dengan materi. Dalam proses penyajian materi, guru mengajak siswa ikut terlibat aktif dalam proses pembelajaran dengan mengamati setiap gambar yang ditunjukan oleh guru atau oleh temannya. Kemudian, gambar-gambar tersebut dipasang sesuai urutan yang logis melalui pemilihan siswa dengan cara undian. Melalui urutan tersebut, guru menanyakan alasan atau dasar pemikiran untuk menanamkan konsep atau materi sesuai dengan kompetensi yang ingin dicapai. Setelah itu siswa diberikan tes akhir untuk mengetahui hasil pembelajaran yang diterapkan. Hasilnya, rata-rata skor hasil belajar siswa kelas kontrol pada pembelajaran IPS tanpa menggunakan model pembelajaran kooperatif teknik picture and picture adalah sebesar 76,5. Sedangkan, rata-rata skor hasil belajar siswa kelas eksperimen pada pembelajaran IPS dengan menggunakan model pembelajaran kooperatif teknik Picture and Picture adalah sebesar 88,86.

Model kooperatif tipe picture and picture memberikan pengaruh yang sangat tinggi terhadap hasil belajar siswa dalam pembelajaran IPS untuk siswa SD. Tipe picture and picture mengharuskan peneliti/guru menyiapkan gambar-gambar yang berkaitan dengan materi pada pelajaran IPS. Untuk mengetahui hasil pembelajaran, siswa harus diberikan tes sebelum dilakukan pembelajaran dan setelah pembelajaran agar dapat diketahui perbedaan antara pembelajaran konvensional dengan pembelajaran kooperatif tipe picture and picture. Seperti yang telah diketahui, siswa akan lebih senang 
dalam memahami suatu hal melalui gambar daripada tulisan. Hal ini terlihat dari hasil tes setelah diterapkannya pembelajaran ini. Meskipun nilai gain tidak terlalu signifikan, namun pelaksanaan pembelajaran ini dianggap berhasil meningkatkan hasil belajar siswa menjadi lebih baik dan mereka lebih mudah memahami materi melalui petunjuk gambar.

Pada penelitian yang dilakukan oleh (Nilasari \& Subroto, 2013) dengan judul "Penerapan Model Pembelajaran Kooperatif Tipe NHT Untuk Meningkatkan Hasil Belajar IPS Kelas V SDN Sidoarjo" dengan pengumpulan data melalui metode observasi, tes, dan wawancara. Hasil penelitian menunjukkan bahwa rata-rata nilai yang diperoleh pada siklus I sebesar 57,50 (40\%), siklus II sebesar 69,10 (60\%), dan siklus III sebesar 82,60 (95\%). Selain itu, dari hasil penelitian juga menunjukkan adanya peningkatan aktivitas guru, aktivitas siswa, afektif siswa, dan psikomotor siswa. Melalui tipe $N H T$, aktivitas guru dalam menyampaikan materi meningkat dari siklus I sebesar $73 \%$ ke siklus II menjadi $85 \%$, kemudian pada siklus III menjadi 95\%. Untuk aktivitas siswa yang sebelumnya pada siklus I hanya $74 \%$ menjadi $86 \%$ pada siklus II dan meningkat pada siklus III sebesar $92 \%$. Kemudian pada tingkat afektif siswa dari $78 \%$ pada siklus I menjadi $81 \%$ pada siklus II dan meningkat menjadi $91 \%$ pada siklus III. Selanjutnya, psikomotor siswa memiliki nilai $71 \%$ pada siklus I menjadi $88 \%$ pada siklus II dan meningkat menjadi $92 \%$ pada siklus III.

Penelitian lain oleh (Mana'a et al., 2014) dengan judul "Meningkatkan Hasil Belajar Siswa Pada Pembelajaran IPS Dengan Menggunakan Pembelajaran Koperatif Tipe Numbered Heads Together di Kelas IV SDN Lalong Kecamatan Tinangkung Utara Kabupaten Banggai Kepulauan" melalui teknik pengumpulan data tes tertulis dan observasi. Hasil belajar siswa dapat dilihat dari daya serap, ketuntasan, dan posttest siswa sebagai berikut: a) Daya serap siswa pada siklus I memperoleh nilai rata-rata 66,29 meningkat pada siklus II menjadi 81,95; b) Ketuntasan siswa pada siklus I dengan hasil tidak tuntas meningkat pada siklus II dengan hasil yang tuntas; c) Posttest yang diperoleh siswa pada siklus I memperoleh nilai 68,45 meningkat pada siklus II dengan nilai rata-rata 85,87.

Selanjutnya, penelitian yang dilakukan oleh (Prasetyo, 2017) dengan judul "Meningkatkan Prestasi Belajar Ips Materi Sumber Daya Alam Melalui Penerapan Model Pembelajaran Kooperatif Tipe Numbered Head Together (NHT) Pada Siswa Kelas IV SD Negeri Jatisarono Kabupaten Kulon Progo Tahun Ajaran 2013/2014" dengan jenis penelitian ini adalah Penelitian Tindakan Kelas (PTK). Sebelum pelaksanaan pembelajaran, nilai rata-rata siswa adalah 62,5 dengan jumlah siswa yang mencapai kriteria ketuntasan minimum adalah 8 orang. Setelah penerapan pembelajaran $N H T$, pada siklus I nilai rata-rata siswa menjadi 70 dengan jumlah siswa yang mencapai kriteria ketuntasan minimum adalah 17 orang, kemudian pada siklus II meningkat menjadi 24 siswa mencapai kriteria ketuntasan minimum dengan nilai rata-rata 80 . Selain itu, keaktifan siswa meningkat dengan rata-rata sebesar $12,09 \%$ dari siklus I yaitu $73,85 \%$ menjadi $85,94 \%$ pada siklus II.

Kemudian, penelitian (Maponga \& Anse, 2020) dengan judul "Meningkatkan Hasil Belajar IPS Melalui Penerapan Model Pembelajaran Kooperatif Tipe Numbered Heads Together (NHT) di Kelas VI SDN 1 Koroha" menghasilkan peningkatan pada aktivitas guru dan siswa telah mencapai indikator keberhasilan yaitu $80 \%$. Kegiatan pembelajaran diawali dengan memberikan apersepsi agar siswa memiliki gambaran pengetahuan yang diperolehnya dan menyampaikan tujuan pembelajaran yang akan dicapai. Pada kegiatan inti, guru mengorganisasikan siswa dalam 7 kelompok, kemudian memberikan masalah dalam bentuk LKS untuk diselesaikan sesuai dengan hasil eksperimen yang dilakukan masing-masing ketua kelompok, dan setelah itu tiap kelompok mempersentasekan hasil pekerjaan kelompoknya. Di akhir pembelajaran, guru memberikan evaluasi untuk mengetahui hasil belajar siswa telah mengikuti proses pembelajaran. Hasil dari penelitian ini, antara lain 1) aktivitas guru pada siklus I pertemuan pertama sebesar $62,5 \%$ dan pada pertemuan kedua sebesar $75 \%$, meningkat pada siklus II pertemuan pertama menjadi $87,5 \%$ dan pertemuan kedua $100 \%$; 2) aktivitas siswa pada siklus I pertemuan pertama sebesar $62,5 \%$ dan pada pertemuan kedua sebesar $75 \%$, meningkat pada siklus II pertemuan pertama menjadi 87,5\% dan pertemuan kedua $100 \%$; 3 ) rata-rata hasil belajar siswa pada siklus I sebesar 73 dengan ketuntasan klasikal sebesar $72 \%$ meningkat pada siklus II menjadi 81,2 dengan persentase ketuntasan klasikal sebesar 92\%.

Terakhir adalah penelitian milik (Syah, 2018) dengan judul "Penerapan Model Pembelajaran Kooperatif Tipe NHT Untuk Meningkatkan Hasil Belajar IPS Siswa Kelas VI SD Negeri 016 Bukit Timah Kecamatan Dumai Selatan" dengan teknik pengumpulan data melalui observasi dan tes. Hasil dari penelitian ini adalah tingkat aktivitas guru semakin baik dengan jumlah skor dari 58,3\% pada pertemuan pertama menjadi $95,8 \%$ pada pertemuan keempat. Kemudian, aktivitas siswa semakin baik 
dari $54,2 \%$ menjadi $91,7 \%$, serta hasil belajar yang meningkat dari nilai rata-rata 55,25 pada siklus I menjadi 85,75 pada siklus II.

Berdasarkan 5 penelitian tersebut, dapat diketahui bahwa model pembelajaran kooperatif tipe NHT memberikan peningkatan hasil belajar siswa dengan baik. Selain itu, guru menjadi ikut berperan aktif dalam pembelajaran. Hal ini terlihat dari persentase aktivitas guru yang semakin meningkat sehingga memberikan dampak baik pada kedekatan guru dan siswa. Melalui pembelajaran tipe NHT, siswa menjadi semakin aktif selama pembelajaran berlangsung.

Model pembelajaran merupakan pola yang digunakan sebagai pedoman dalam merencanakan pembelajaran di kelas, termasuk di dalamnya adalah penyusunan kurikulum, mengatur materi, menentukan tujuan-tujuan pembelajaran, menentukan tahap-tahap dalam kegiatan pembelajaran, lingkungan pembelajaran, dan pengelolaan kelas (Daryanti \& Taufina, 2020; Marina, 2016; Utama \& Sari, 2015). Pembelajaran kooperatif merupakan sebuah strategi pembelajaran yang melibatkan peran aktif siswa dalam kerjasama kelompok untuk mencapai tujuan bersama. Siswa yang belajar menggunakan model pembelajaran kooperatif akan memiliki motivasi yang tinggi karena didorong dan didukung dari rekan sebaya (Apriandi, 2012; Marasiwi, 2017; Sutriningsih et al., 2018). Dalam penerapannya, model pembelajaran kooperatif memiliki berbagai tipe dalam pelaksanaannya agar sesuai dengan tujuan yang ingin dicapai. Tujuan-tujuan tersebut, antara lain meningkatkan prestasi belajar, menerima kemajemukan latar belakang siswa dalam berkelompok, dan mengembangkan keterampilan sosial melalui belajar kelompok (Kusumawati \& Mawardi, 2016; Rahmi \& Adnan, 2019; Susanto \& Ayuni, 2017).

Model pembelajaran kooperatif menggunakan tipe picture and picture merupakan salah satu strategi pembelajaran kepada siswa agar mereka tidak merasa bosan dengan mata pelajaran IPS. Model pembelajaran picture and picture memberikan siswa contoh gambar-gambar yang sudah disiapkan oleh guru dalam bentuk kartu maupun cerita bergambar, selama pembelajaran setiap kelompok harus berdiskusi dan saling membagi tugas untuk menjelaskan setiap materi dalam gambar yang disajikan (Astuti et al., 2020; Handayani et al., 2017; Susanti \& Kusmariyani, 2017). Melalui gambar-gambar tersebut, siswa akan mengurutkan/memasangkan setiap gambar agar menjadi urutan yang logis sehingga siswa juga bisa berpikir dengan logis dan kritis, maka tujuan untuk meningkatkan motivasi belajar dan berpikir kritis akan tercapai melalui model pembelajaran kooperatif tipe picture and picture (Mayasari \& N, 2019; Passalowongi, 2020; Rosmalem, 2017). Sedangkan, model pembelajaraan kooperatif lainnya yang dapat diterapkan adalah tipe Number Heads Together (NHT).

Penerapan model pembelajaran kooperatif tipe NHT merupakan suatu model pembelajaran yang lebih melibatkan banyak siswa dalam menelaah materi dalam suatu pelajaran dan mengecek pemahaman siswa tentang isi pelajaran tersebut, pembelajaran ini akan lebih meningkatkan kerja sama antar siswa (Aprilia, 2018; Jahring, 2020; Murwanto, 2020). NHT adalah suatu tipe dari pengajaran kooperatif pendekatan struktural yang memberikan kesempatan kepada siswa untuk saling membagikan ide-ide dan mempertimbangkan jawaban yang paling tepat, penggunaan tipe $N H T$ pada penerapan pembelajaran kooperatif agar siswa dapat belajar melalui kegiatan bermain, berlomba dan bekerjasama dalam tim (Elida, 2018; Sulastri, 2020; Sumarni, 2016). Siswa diajak untuk belajar berkelompok dan diberikan nomor anggota di masing-masing kepala siswa, mereka akan berdiskusi mengenai tugas dan materi yang telah diberikan oleh guru, jika guru menyebutkan nomor yang sesuai pada salah satu nomor anggota, maka siswa akan mengangkat tangan dan menjawab pertanyaannya. Melalui penerapan metode pembelajaran kooperatif tipe $N H T$, maka siswa akan semakin aktif selama pembelajaran dan meningkatkan hasil belajar.

Penelitian ini didukung dengan beberapa penelitian sebelumnya yaitu, pertama penelitian yang dilaksanakan oleh (Handayani et al., 2017), memperoleh hasil bahwa model pembelajaran picture and picture berbantuan media audio-visual berpengaruh terhadap kompetensi pengetahuan IPA. Kedua, penelitian yang dilaksanakan oleh (Daryanti \& Taufina, 2020), memperoleh hasil bahwa penggunaan media pembelajaran dalam model picture and picture untuk meningkatkan hasil belajar siswa. Ketiga, penelitian yang dilaksanakan oleh (Sumarni, 2016), memperoleh hasil bahwa penerapan model pembelajaran Numbered Heads Together dengan pemanfaatan alat peraga sederhana terbukti dapat meningkatkan kemampuan berhitung.

Implikasi dari pelaksanaan penelitian ini adalah meningkatkan motivasi belajar, kemampuan berpikir kritis, siswa akan aktif selama pembelajaran dan dapat meningkatkan hasil belajar siswa. 


\section{Simpulan}

Dapat disimpulkan dari hasil dan pembahasan 10 artikel berdasarkan hasil pembelajaran dan rata-rata nilai gain yang diperoleh, maka model pembelajaran kooperatif tipe Number Heads Together (NHT) lebih efektif untuk diimplementasikan dibandingkan model pembelajaran picture and picture dalam pelajaran IPS siswa sekolah dasar. Implikasi penelitian ini adalah meningkatkan motivasi belajar, kemampuan berpikir kritis, siswa akan aktif selama pembelajaran dan dapat meningkatkan hasil belajar siswa.

\section{Daftar Pustaka}

Ani, N. K. K., Darsana, I. W., \& Asri, I. G. A. A. S. (2017). Pengaruh Model Pembelajaran Time Token Berbasis Tri Hita Karana Terhadap Hasil Belajar IPS Siswa Kelas V SD Gugus VIII Kecamatan Gianyar Tahun Ajaran 2016/2017. Mimbar PGSD Undiksha, 5(2). https://doi.org/10.23887/jjpgsd.v5i2.11018

Apriandi, D. (2012). Efektivitas Model Pembelajaran Kooperatif Tipe Two Stay-Two Stray (TS-TS) Dan Numbered Heads Together (NHT) Terhadap Prestasi Belajar Matematika Siswa Kelas VIII SMP Di Kabupaten Bantul Ditinjau Dari Aktivitas Belajar. Jurnal Ilmiah Pendidikan Matematika, 1(1). https://doi.org/10.25273/jipm.v1i1.467

Aprilia, L. A. (2018). Meningkatkan Hasil Belajar Ppkn Melalui Model Pembelajaran Numbered Heads Together (Nht) Berbasis Kurikulum 2013. Wacana Akademika: Majalah Ilmiah Kependidikan, 2(1). https://doi.org/10.30738/wa.v2i1.2530

Astuti, H. P., Nugroho, A. A. E., \& Dewi, N. A. R. (2020). Penerapan Model Pembelajaran Picture and Picture Berbasis Keanekaragaman Hayati Dalam Pembentukan Empati Anak Usia Dini. Intuisi : Jurnal Psikologi Ilmiah, 12(1), 66-74. https://doi.org/10.15294/intuisi.v12i1.23573

Daryanti, D., \& Taufina, T. (2020). Penggunaan Media Pembelajaran dalam Model Picture and Picture untuk meningkatkan Hasil Belajar Siswa. Jurnal Basicedu, 4(2), 484-490. https://doi.org/10.31004/basicedu.v4i2.368

Elida. (2018). Peningkatan Motivasi Belajar Pkn Siswa Kelas IX. 7 Smp 21 Kota Pekanbaru Melalui Penerapan Model Pembelajaran Kooperatif Tipe Number Heads Together. Dinamisia : Jurnal Pengabdian Kepada Masyarakat, 2(1), 135-143. https://doi.org/10.31849/dinamisia.v2i1.1077

Fauziah, T., \& Bermawi, Y. (2014). Penerapan Model Kooperatif Tipe Picture and Picture Pada Materi Peninggalan Sejarah di Sekolah Dasar Negeri Banda Aceh. Jurnal Pesona Dasar, 2(3), 79-87. http://www.jurnal.unsyiah.ac.id/PEAR/article/view/7503

Handayani, N. M. D., Ganing, N. N., \& Suniasih, N. W. (2017). Model Pembelajaran Picture and Picture Berbantuan Media Audio-Visual Terhadap Kompetensi Pengetahuan IPA. Journal of Education Technology, 1(3), 176-182. https://doi.org/10.23887/jet.v1i3.12502

Ilham, M., \& Hardiyanti, W. E. (2020). Pengembangan Perangkat Pembelajaran Ips Dengan Metode Saintifik Untuk Meningkatkan Kemampuan Berpikir Kritis Siswa Materi Globalisasi Di Sekolah Dasar. Jurnal Ilmiah Pendidikan Dasar, 7(1), 12-29. https://doi.org/10.30659/pendas.7.1.1229

Indrawan, I. W. A., Manuaba, I. B. S., \& Sujana, I. W. (2017). Pengaruh Model Pembelajaran TTW Berbasis Tri Hita Karana Terhadap Kompetensi Pengetahuan IPS. Mimbar PGSD Undiksha, 5(2). https://doi.org/10.23887/jjpgsd.v5i2.10632

Jahring, J. (2020). Kemampuan Koneksi Matematis Pada Model Pembelajaran CORE Dan NHT. AKSIOMA: Jurnal Program Studi Pendidikan Matematika, 9(1), 182-189. https://doi.org/10.24127/ajpm.v9i1.2667

Kristin, F. (2016). Efektivitas Model Pembelajaran Kooperatif Tipe STAD Ditinjau Dari Hasil Belajar IPS Siswa Kelas 4 SD. Scholaria: Jurnal Pendidikan Dan Kebudayaan, 6(2), 74-79. 
https://ejournal.uksw.edu/scholaria/article/view/230

Kusumawati, H., \& Mawardi, M. (2016). Perbedaan Penerapan Model Pembelajaran Kooperatif Tipe NHT Dan STAD Ditinjau Dari Hasil Belajar Siswa. Scholaria: Jurnal Pendidikan Dan Kebudayaan, 6(3), 251-263. https://doi.org/10.24246/j.scholaria.2016.v6.i3.p251-263

Mana'a, S., Saneba, B., \& Palimbong, A. (2014). Meningkatkan Hasil Belajar Siswa Pada Pembelajaran IPS Dengan Menggunakan Pembelajaran Koperatif Tipe Numbered Heads Together di Kelas IV SDN Lalong Kecamatan Tinangkung Utara Kabupaten Banggai Kepulauan. Jurnal Kreatif Tadulako Online, $3(3), \quad 1-12$. http://jurnal.untad.ac.id/jurnal/index.php/JKTO/article/view/3194

Maponga, R. D., \& Anse, L. (2020). Meningkatkan Hasil Belajar IPS Melalui Penerapan Model Pembelajaran Kooperatif Tipe Numbered Heads Together (NNT) di Kelas VI SDN 1 Koroha. Journal of Basication (Job): Jurnal Pendidikan Dasar, 3(3), 123-128. https://doi.org/10.36709/jobpgsd.v3i3.14407

Marasiwi, M. (2017). Penerapan Model Pembelajaran Kooperatif Tipe Numbered Heads Together (NHT) Untuk Meningkatkan Prestasi Belajar Matematika Siswa. Premiere Educandum, 7(1), 1927. https://doi.org/10.25273/pe.v7i01.1140

Marina, C. (2016). Peningkatan Pemahaman Konsep dan Hasil Belajar Materi Penyesuaian Makhluk Hidup Dalam Pembelajaran Kooperatif Tipe Think-Pair-Share Dipadu dengan Model Picture and Picture yang Dikembangkan Melalui Lesson Study. JINOP (JURNAL INOVASI PEMBELAJARAN), 2(1), 256-269. https://doi.org/10.22219/jinop.v2i1.3284

Mayasari, S., \& N, L. (2019). Penerapan Model Pembelajaran Kooperatif Tipe Picture And Picture Untuk Meningkatkan Hasil Belajar IPS Siswa Kelas III SD Negeri 37 Pekanbaru. Jurnal Pajar (Pendidikan Dan Pengajaran), 3(2), 313-318. https://doi.org/10.33578/pjr.v3i2.6659

Mikaningsih, J. N. A. (2014). Penenerapan Metode Quantum Teaching Terhadap Hasil Belajar IPS Siswa Kelas II SDN Gading 1 Sumenep. Pedagogia: Jurnal Pendidikan, 3(1), 28-36. https://doi.org/10.21070/pedagogia.v3i1.54

Murwanto, S. (2020). Implementasi Model Pembelajaran Kooperatif Tipe NHT ( Numbered-HeadTogether ) untuk Meningkatkan Hasil Belajar IPA Siswa Kelas IX B SMP Negeri 4 Alla Enrekang. Jurnal Sainsmat, 9(1), 14-28. https://doi.org/10.35580/sainsmat91141872020

Nilasari, E. P., \& Subroto, W. T. (2013). Penerapan Model Pembelajran Kooperatif Tipe NHT Untuk Meningkatkan Hasil Belajar IPS Kelas V SDN Sidoarjo. Jurnal Penelitian Pendidikan Guru Sekolah Dasar, 1(2), 1-10. https://jurnalmahasiswa.unesa.ac.id/index.php/jurnal-penelitianpgsd/article/view/2956

Otiarka, A. F., \& Susilo, T. D. (2017). Meningkatkan Hasil Belajar Siswa Dengan Model Pembelajaran Kooperatif Picture and Picture Berbantuan Media Stik Keberuntungan. Jurnal Mitra Pendidikan, 1(6), 640-614. https://e-jurnalmitrapendidikan.com/index.php/e-jmp/article/view/144

Paramita, N. M. A. S., Rati, N. W., \& Tristiantari, N. K. D. (2019). Pengaruh Model Pembelajaran Picture And Picture Berorientasi Pendidikan Karakter Terhadap Motivasi Belajar Ips Siswa Kelas V. Journal Of Education Technology, 3(1), 1-8. https://doi.org/10.23887/Jet.V3i1.17957

Passalowongi, N. (2020). Meningkatkan Hasil Belajar Tema Lingkungan Tempat Tinggalku Melalui Model Pembelajaran Picture and Picture Siswa Kelas IV SD Negeri 18 Coppeng-Coppeng Kabupaten Barru. Jurnal Studi Guru Dan Pembelajaran, 3(2), 275-282. https://doi.org/10.30605/jsgp.3.2.2020.341

Pitriani, N. W., Ardana, I. K., \& Kristiantari, M. G. R. (2017). Pengaruh Model Pembelajaran Think Pair Share Berbantuan Audio Visual Terhadap Kompetensi Pengetahuan IPS. Mimbar PGSD, 5(2), 19. https://doi.org/10.23887/jjpgsd.v5i2.10789 
Prasetyo, R. S. J. (2017). Meningkatkan Prestasi Belajar Ips Materi Sumber Daya Alam Melalui Penerapan Model Pembelajaran Kooperatif Tipe Numbered Head Together (NHT) Pada Siswa Kelas IV SD Negeri Jatisarono Kabupaten Kulon Progo Tahun Ajaran 2013/2014. Jurnal PGSD Indonesia, 3(2), 1-7. http://ojs.upy.ac.id/ojs/index.php/jpi/article/view/994

Pratama, G. H. A. (2018). Pengaruh Model Pembelajaran Crh Berbantuan Media Audio Visual Terhadap Hasil Belajar IPS. Mimbar Ilmu, 23(1), 131-141. https://doi.org/10.23887/mi.v23i1.16402

Rahmi, S. O., \& Adnan, F. (2019). Penerapan Model Pembelajaran Kooperatif Tipe Numbered Head Together (NHT) Terhadap Hasil Belajar Siswa Kelas IV SDN 43 Sungai Sapih Padang. Jurnal Basicedu, 3(2), 666-673. https://doi.org/10.31004/basicedu.v3i2.53

Rohima, Sukmawati, \& Rosnita. (2017). Pengaruh model pembelajaran kooperatif teknik picture and picture terhadap hasil belajar IPS siswa SD. Jurnal Pendidikan Dan Pembelajaran Khatulistiwa, 6(5). https://jurnal.untan.ac.id/index.php/jpdpb/article/view/20008

Rosmalem. (2017). Peningkatan Aktivitas Belajar Siswa Dengan Model Pembelajaran Picture And Picture Pada Pelajaran Seni Budaya. Jurnal Handayani: Jurnal Kajian Pendidikan Pra Sekolah Dan Pendidikan Dasar, 6(2), 153-161. https://doi.org/10.24114/jh.v6i2.6529

Suasaningdyah, E. (2018). Peningkatan Nilai Peserta Didik Mata Pelajaran IPS Topik Bermain LayangLayang Melalui Pembelajaran Konstektual. Jurnal Pendidikan (Teori Dan Praktik), 2(2), 105. https://doi.org/10.26740/jp.v2n2.p105-115

Sulastri, S. (2020). Peningkatan Kemandirian Belajar IPA dengan Penerapan Model Pembelajaran Numbered Heads Together pada Siswa Kelas V SDN 43 Rejang Lebong. Pendipa Journal of Science Education, 4(3), 46-51. https://doi.org/10.33369/pendipa.4.3.46-51

Sumarni, S. (2016). Upaya Meningkatkan Kemampuan Berhitung Melalui Penerapan Model Pembelajaran Numbered Heads Together Dengan Pemanfaatan Alat Peraga Sederhana Materi Pembagian Siswa Kelas II. Refleksi Edukatika: Jurnal Ilmiah Kependidikan, 7(1), 61-68. https://doi.org/10.24176/re.v7i1.1813

Susanti, P. A., \& Kusmariyani, N. N. (2017). Penerapan Model Picture And Picture Berbasis Pendekatan Saintifik Untuk Meningkatkan Hasil Pengetahuan IPA. Jurnal Ilmiah Sekolah Dasar, 1(2), 99. https://doi.org/10.23887/jisd.v1i2.10144

Susanto, F., \& Ayuni, I. R. (2017). Pengembangan Perangkat Pembelajaran Model Kooperatif Tipe NHT Dengan Strategi Pemecahan Masalah (Problem Solving) Sistematis Bagi Peserta Didik SMP Di Kabupaten Pringsewu. Jurnal Aksioma, 6(3), 301-307. https://doi.org/10.24127/ajpm.v6i3.1054

Susiloningsih, W. (2016). Model Pembelajaran CTL (Contextual Teaching and Learning) dalam Meningkatkan Hasil Belajar Mahasiswa PGSD Pada MataKuliah Konsep IPS Dasar. Pedagogia: Jurnal Pendidikan, 5(1), 57. https://doi.org/10.21070/pedagogia.v5i1.89

Sutriningsih, N., Pratiwi, R., \& Utami, B. H. S. (2018). Penerapan Model Pembelajaran Kooperatif Tipe Numbered Head Together (NHT) pada Materi Sistem Persamaan Linear Dua Variabel (SPLDV). Jurnal E-Dumath, 4(2), 11-20. https://doi.org/10.26638/je.717.2064

Syah, A. (2018). Penerapan Model Pembelajaran Kooperatif Tipe NHT Untuk Meningkatkan Hasil Belajar IPS Siswa Kelas VI SD Negeri 016 Bukit Timah Kecamatan Dumai Selatan. Jurnal Pajar (Pendidikan Dan Pengajaran), 2(3), 346-350. https://doi.org/10.33578/Pjr.V2i3.5527

Tanjung, N. (2018). Peningkatan Hasil Belajar Ips Melalui Model Pembelajaran Kooperatif Picture and Picture Siswa Kelas V A SD Negeri 200402 Sabungan Padangsidimpuan 2017- 2018. Ristekdik: Jurnal Bimbingan Dan Konseling, 3(2), 45-48. https://doi.org/10.31604/Ristekdik.2018.V3i2.45-48

Utama, M., \& Sari, D. L. (2015). Keefektifan Model Pembelajaran Picture And Picture Dan Make A Match Ditinjau Dari Hasil Belajar Dalam Pembelajaran IPA Kelas 4 SD Gugus Mawar - Suruh. Scholaria: Jurnal Pendidikan Dan Kebudayaan, 5(3), 82-99. https://doi.org/10.24246/j.scholaria.2015.v5.i3.p82-99 